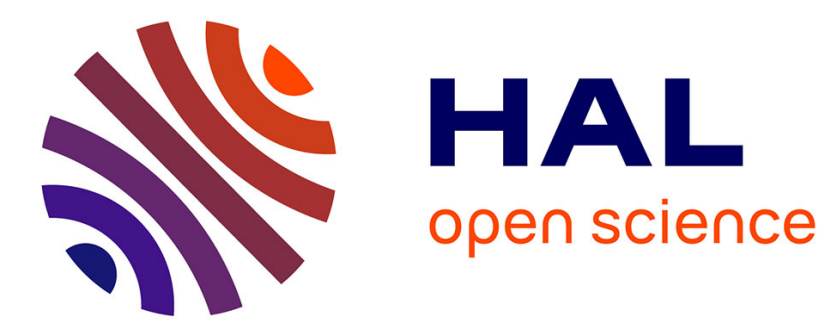

\title{
Interface characterization by pull-out test between high modulus polyethylene fibre and an unsaturated polyester resin
}

\author{
P. Masse, J. Cavrot, P. François, J. Lefebvre, B. Escaig
}

\section{- To cite this version:}

P. Masse, J. Cavrot, P. François, J. Lefebvre, B. Escaig. Interface characterization by pull-out test between high modulus polyethylene fibre and an unsaturated polyester resin. Journal de Physique IV Proceedings, 1993, 03 (C7), pp.C7-1661-C7-1664. 10.1051/jp4:19937260 . jpa-00251900

\author{
HAL Id: jpa-00251900 \\ https://hal.science/jpa-00251900
}

Submitted on 1 Jan 1993

HAL is a multi-disciplinary open access archive for the deposit and dissemination of scientific research documents, whether they are published or not. The documents may come from teaching and research institutions in France or abroad, or from public or private research centers.
L'archive ouverte pluridisciplinaire HAL, est destinée au dépôt et à la diffusion de documents scientifiques de niveau recherche, publiés ou non, émanant des établissements d'enseignement et de recherche français ou étrangers, des laboratoires publics ou privés. 


\title{
Interface characterization by pull-out test between high modulus polyethylene fibre and an unsaturated polyester resin
}

\author{
P. MASSE, J.P. CAVROT, P. FRANCOIS, J.M. LEFEBVRE and B. ESCAIG
}

Laboratoire de Structure et Propriétés de l'Etat Solide, Université des Sciences et Technologies de Lille, Bâtiment C6, 59655 Villeneuve d'Ascq, France

The observation of the pull-out conditions for a monofilament outside a matrix has been applied to a wide variety of organic or inorganic materials, as a direct method of interface characterization.

In the case of High Modulus PolyEthylene (HMPE) it has been demonstrated that oxygen plasma treatments or gamma irradiation modify the fibre surface properties and improve the adhesion between the fibre and a resin. In this study, the effect of different plasma treatment times and the irradiation conditions leading to different gel fractions have been tested. For plasma treatments, an appreciable improvement occurs even for the lower residence times $(2 \mathrm{sec})$. The gamma irradiation has only the same efficiency for the condition leading to a high gel fraction $(0.75)$. These results agree with InterLaminar Shear Strengths (ILSS) values measured in three-point bending on HMPE/cpoxy laminates.

\section{Introduction}

Single fibre pull-out test is a direct method for measuring the fibre matrix interface properties by the evaluation of a mean interface shear strength. To know this value is important to appreciate the intensity of bonding between the constituants of the composite after adjustment of the fibre surface treatment. In this way, single fibre pull-out tests have been performed on High Modulus PolyEthylene (HMPE) fibre/Unsaturated Polyester (UP) resin system in order to estimate the adhesion improvement brought by different treatments of the polyethylene (plasma or irradiation).

\section{Materials}

Polyethylene filaments (producted by SNIA FIBRE, Milan, Italy) were prepared by melt spinning from linear polymer stretched to a final draw ratio of 30 , giving a mean filament diameter of $15 \mu \mathrm{m}$. The mechanical and physical properties of SNIA fibre are shown above.

$\begin{array}{ccccc}\text { Young Modulus } & \text { Tensilc Strength } & \text { Density } & \text { Mw } & \mathrm{Mn} \\ 50 \mathrm{GPa} & 1,3 \mathrm{GPa} & 0,96 & 130000 & 120000\end{array}$


Plasma and gamma treatments have been performed at I. R. C in Polymer Science and Technology, University of Leeds (UK). In the plasma treatment the fibre is exposed to a reactive monoatomic oxygen gas. Three different residence times in the treatment tube have been used $(2 \mathrm{sec}, 10 \mathrm{sec}, 10 \mathrm{~min})$. The gamma irradiation treatments using a cobalt source have been performed in an acetylene atmosphere. In this study two irradiation conditions leading to a gel fraction of 0.61 and 0.75 have been tested.

The unsaturated polyester resin produced by CRAY VALLEY (Drocourt, France) is a terpolymer of maleic anhydride, propylene glycol and isophtalic acid dissolved in styrene used as the cross-linking agent.

\section{Pull-out tests}

A monofilament embedded at one end in a botton of resin is tested in tension. For the lower embedded lengths, a fibre decohesion followed by pull-out is observed. The variation of the decohesion force with the embedded length is related to the shear strength of the interface, and permits to evaluate the efficiency of different surface treatments.

Several pull-out equipments for rigid fibres have been already described in the literature $(1,2)$, but because of the flexible nature of HMPE a special frame has been built for sample preparation allowing to maintain the fibre taut during resin curing and to choose the fibre free length and the fibre embedded length ( adjustment down to $300 \mu \mathrm{m}$ ). Sample is composed of a fibre threated through two aluminium DSC pans with a centered hole of $100 \mu \mathrm{m}$ in diameter. Pull-out tests have been performed on an Instron machine operated at low crosshead speeds. The aluminium cells linked by the fibre are mounted into small clips without any clamping. As the force developed on fibres are less than $0,1 \mathrm{~N}$, an electronic scale $(0,01 \mathrm{~g}$ in precision) has been used as a load cell. The crosshead speed has been set at $200 \mu \mathrm{m} / \mathrm{min}$, which corresponds to a strain rate of about $10^{-3} \mathrm{sec}^{-1}$.

\section{Results and discussion}

In this study, the debonding force " $F_{A}$ " was simply taken as the maximum force preceding partial debonding ( $\mathrm{pt} A$ in Fig.1). As the diameter of the HMPE is not constant, the representation of the force to actual diameter $D$ ratio instead of the force was adopted; it reduces data scatter.

For each type, $F_{A} / D$ versus embedded length "Le" plots present the same general trend (Fig. 2,3,4). At the lower Le values pull-out occurs at a debonding force which increases with Le. At larger Le values fibre failure occurs outside the resin block. A transition region is observed where the two behavior generally coexist.

The simple model (3), allowing to find a linear relation between $F_{A}$ and Le, a linear regression was systematically tested on the experimental data up to the first failure point (Table). The bad correlation coefficient found for the untreated fibres cast some doubt on the entire reliability of numerical values deduced from such a linear regressions and is probably due to a poor adhesion in this case. An average interface shear strength has been deduced from the slope of the straight lines as $\tau_{\mathrm{i}}=\left(\mathrm{F}_{\mathrm{A}} / \Pi \mathrm{DL} \mathrm{L}\right)$ (3). The failure load has been evaluated as the mean value of the failure data and is marked by a horizontal line in the figures (Fig. 2,3,4). 
The results collected in the table show a strong effect of the plasma treatments even for the lower residence times $(2 \mathrm{sec}$ and $10 \mathrm{sec}$ ). In the presence of oxygen three steps in surface modifications are considered depending on the plasma treatment time (4): (i) the creation of oxygen containing groups, (ii) surface crosslinking, (iii) surface pitting. This latter effect is probably present for the $10 \mathrm{~min}$ treatment and contributes to increase the measured interface shear strength. The main role of irradiation is the polyethylene cross-linking in volume (5), reducing marquedly the creep strain. However for the condition leading to a 0.75 gel fraction, an adhesion improvement of the same order of magnitude than the lower plasma treatment times is also observed.

These results are agree with InterLaminar Shear Strengths (ILSS) measurements on unidirectional composite mentioned in the literature (6).

Acknowledgements

Financial support from BRITE/EURAM programme under contract BREU/BE 3565 is gratefully acknowledged as well as the fruitful cooperation with the IRC in Polymer Science at the University of Leeds (Prof. I. M. Ward).

References

1- PIGGOTT M. R. , CHUA P. S. , ANDISON D., Polym. Comp $\underline{6}$ (1985) 242

2- DESARMOT G., SANCHEZ M., Comptes rendus des quatrièmes journées nationales sur les composites, VERCHERY G. Editor, Pluralis, Paris, (1986) 3- CHUA P. S., PIGGOTT M. R., Comp. Sci. Technol. 22 (1985) 107

4- TISSINGTON B., POLlard G., WARD I. M., Comp. Sci. Technol. 44 (1992) 182

5- WOODS D. W., WARD I. M., Plast. Rubb. Proc. Appl. 18 (1992) 255

6- TISSINGTON B., POLLARD G., WARD I. M., J. Mat. Sci 26 (1991) 82

\begin{tabular}{|c|c|c|c|c|}
\hline HMPE & $\mathrm{A}$ & $\begin{array}{c}\tau \\
(\mathrm{MPa})\end{array}$ & $\begin{array}{c}\text { Lac } \\
(\mathrm{mm})\end{array}$ & $\begin{array}{c}\text { or } \\
(\mathrm{MPa})\end{array}$ \\
\hline UNTREATED & 0.67 & $0.4 \pm 0.3$ & 2.8 & 470 \\
\hline $\begin{array}{l}\text { PLASMA TREATED } \\
2 \text { sec }\end{array}$ & 0.92 & $1.1 \pm 0.2$ & 1.6 & 610 \\
\hline $\begin{array}{l}\text { PLASMA TREATED } \\
10 \mathrm{sec}\end{array}$ & 0.91 & $1.1 \pm 0.2$ & 1.4 & 527 \\
\hline $\begin{array}{l}\text { PLASMA TREATED } \\
10 \mathrm{~min}\end{array}$ & 0.84 & $1.9 \pm 0.2$ & 0.9 & 530 \\
\hline $\begin{array}{l}\text { CROSS-LINKEO } \\
61 \% \text { GEL FRACTION }\end{array}$ & 0.84 & $0.6 \pm 0.2$ & 3.3 & 670 \\
\hline $\begin{array}{l}\text { CROSS-LINKED } \\
75 \% \text { GEL FRACTION }\end{array}$ & 0.94 & $1.2 \pm 0.2$ & 1.8 & 661 \\
\hline
\end{tabular}

- R correlation coefficient

- $\tau_{i}$ average interface shear strength

- Lec critical embedied length

- or average failure stress

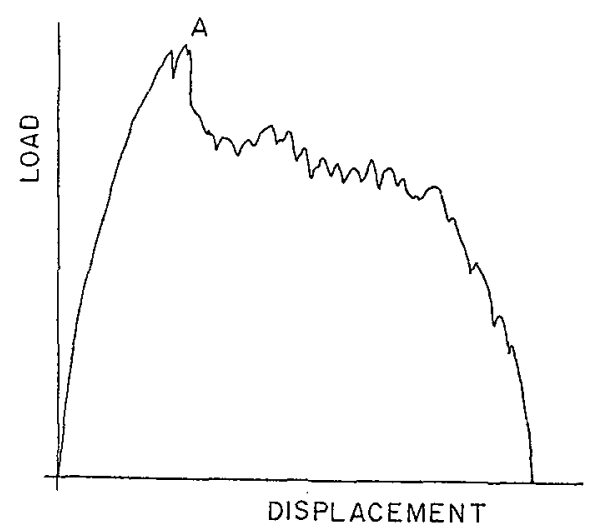




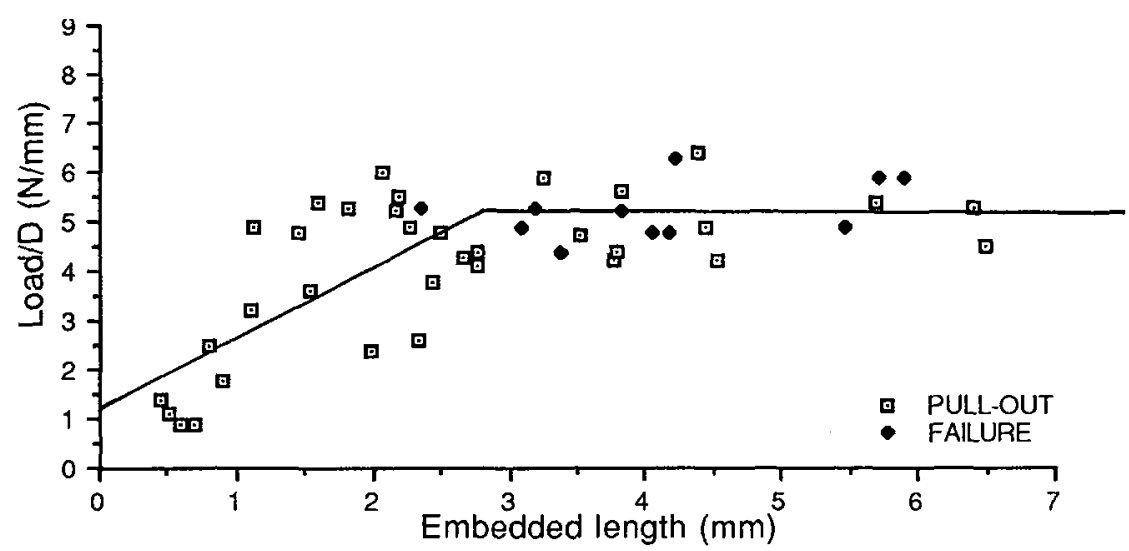

Figure 2 Pull-out/failure load versus embedded length for untreated fibre

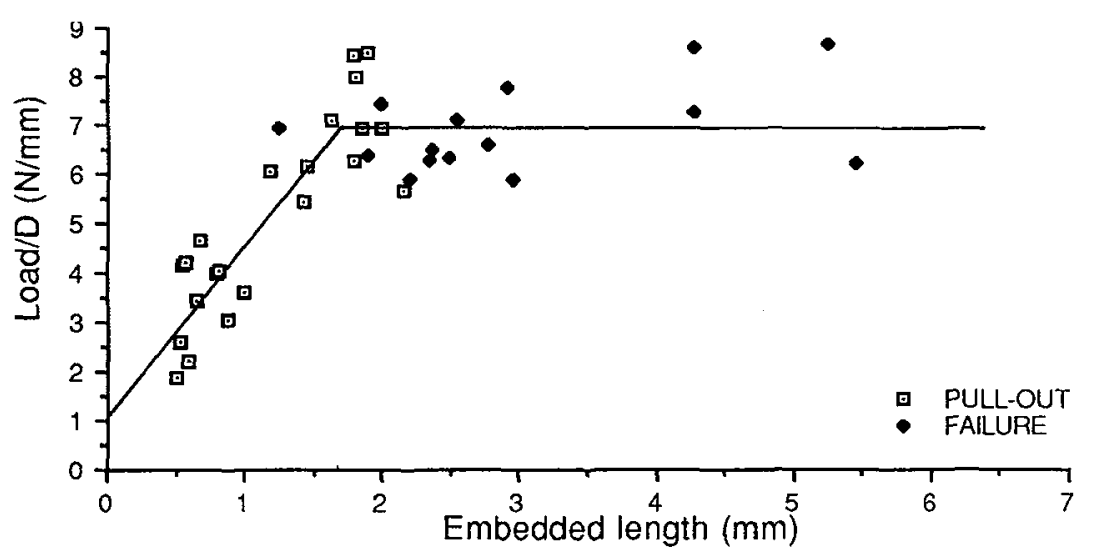

Figure 3 Pull-out/Failure load versus embedded length for 2 sec plasma treated fibre

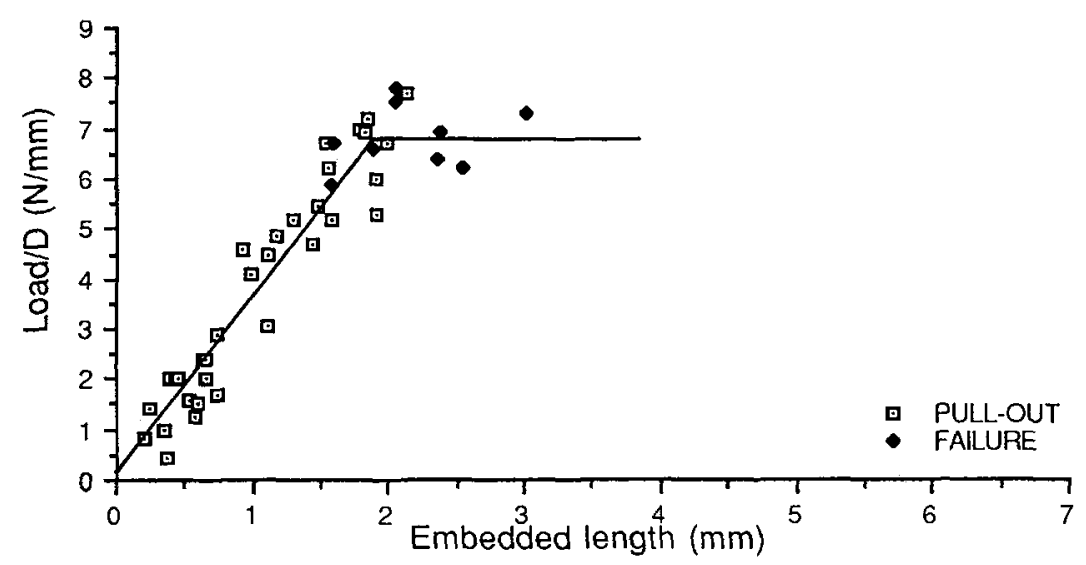

Figure 4 Pull-out/failure load versus embedded length for cross-linked fibre with a $75 \%$ gel fraction 